\title{
Food Plants in the Caatinga
}

\author{
Daline Fernandes de Souza Araújo, Maria Elieidy Gomes de Oliveira, \\ Paloma Oliveira Antonino Assis de Carvalho, Emanuella de Aragão Tavares, \\ Gerlane Coelho Bernardo Guerra, \\ Rita de Cássia Ramos do Egypto Queiroga, \\ Silvana Maria Zucolotto Langassner, Fabrícia França Bezerril, \\ Ana Cristina Silveira Martins, Gracy Kelly Vieira de Vasconcelos Medeiros, \\ Tamires Alcântara Dourado Gomes Machado, \\ and Nadja Maria da Costa Melo
}

\section{Contents}

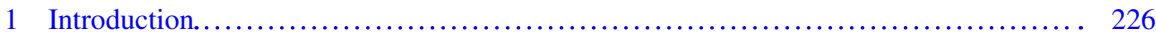

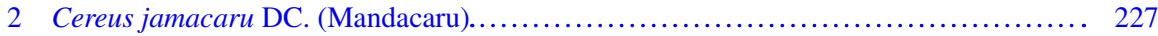

$2.1 \quad$ Species Characteristics.............................................. 227

2.2 Popular Use and Possible Application................................... 228

2.3 Physical-Chemical Characteristics and Nutritional Composition................. 228

2.4 Biological Properties................................................... 230

3 Opuntia ficus-indica (L.) Mill and Nopalea cochenillifera (L.) Salm-Dyck (Palm Species) ............................................................... 232

3.1 Species Characteristics............................................... 232

3.2 Popular Use and Possible Application......................................... 234

3.3 Physical-Chemical Characteristics and Nutritional Composition.................. 234

3.4 Biological Properties................................................. 236

4 Pilosocereus gounellei (Xique-xique)...................................... 237

4.1 Species Characteristics.............................................. 237

4.2 Popular Use and Possible Application.................................... 238

D. F. S. Araújo ( $ه)$

Health Sciences College of Trairi, Federal University of Rio Grande do Norte,

Santa Cruz, Rio Grande do Norte, Brazil

M. E. G. de Oliveira · P. O. A. A. de Carvalho · R. C. R. E. Queiroga · F. F. Bezerril

G. K. V. V. Medeiros · T. A. D. G. Machado

Departament of Nutrition, Federal University of Paraíba, João Pessoa, Paraíba, Brazil

E. d. A. Tavares · S. M. Z. Langassner

Departament of Phamacy, Federal University of Rio Grande do Norte,

Natal, Rio Grande do Norte, Brazil

G. C. B. Guerra - N. M. C. Melo

Department of Biophysics and Pharmacology, Federal University of Rio Grande do Norte, Natal, Rio Grande do Norte, Brazil

A. C. S. Martins

Food of Engineering, Federal University of Paraíba, João Pessoa, Paraíba, Brazil 
4.3 Physical-Chemical Characteristics and Nutritional Composition................ 238

4.4 Biological Properties................................................ 242

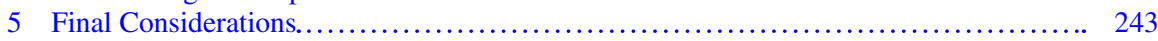

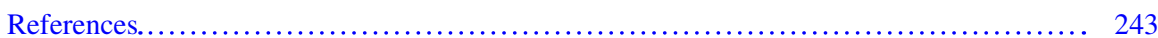

\section{Introduction}

"Famine foods," "alternative food plants," "wild edible plants," "unconventional vegetables," "traditional vegetables," and "unconventional food plants" are names given to a group of underutilized plants which have received these designations in reaction to their extinction due to the expansion of monocultures (Bhandari 1974; Brasil 2010; Kinupp 2004; Leal et al. 2018; Uprety et al. 2012). These native and exotic plants are cultivated spontaneously in nature; however, it appears that they have been little explored. They are often wiped out to make room for the production of other foods that boost the economy, favoring the reduction of an area's biodiversity (Leal et al. 2018). An example of this destruction is cacti that represent a large number and variety of species, found throughout the world due to their great adaptive capacity. Their ecological advantages can be attributed to crassulacean acid metabolism, which allows absorption of $\mathrm{CO}_{2}$ during the night, reducing the loss of water during the process of photosynthesis (Guevara-Figueroa et al. 2010; Mancuso 2019).

The Cactaceae family is widely distributed, encountered from Canada, across the USA, Mexico, and Central and South America. In some countries, such as Mexico and Colombia, several species of Cactaceae family are used in folk medicine. The family is subdivided into three subfamilies Cactoideae, Opuntioidea, Pereskioideae (Barthlott and Hunt 1993) and a new subfamily Maihunioideae qualified to Maihuenia (Weber) Schumann (Anderson 2001).

In Brazil, species like Cereus jamacaru DC., Harrisia adscendens (Gürke) Britton \& Rose, Opuntia ficus-indica (L.) Mill, and Pilosocereus gounellei are popularly used in various diseases as analgesics, antibiotics, diuretics and for coughs and heart disease and to cure certain types of ulcers (Andrade et al. 2006; Lucena et al. 2012). In this chapter, the nutritional composition, biological properties, and use of some of the Caatinga food plants will be presented. 


\section{Cereus jamacaru DC. (Mandacaru)}

\subsection{Species Characteristics}

The Cereus jamacaru is a typical species of the Caatinga biome, located in the semiarid region in northeastern Brazil, including almost all its states (Ceará, Rio Grande do Norte, Paraíba, Pernambuco, Alagoas, Sergipe, Bahia), and extending to the southeast region, in the north of Minas Gerais. This species is also known as mandacaru, cardeiro, jamacaru, thistle, cardon, caxabú, and wild fig (Andrade et al. 2006; Lucena et al. 2015; Santos et al. 2017; Silva et al. 2019). Other species of Cereus are found in other regions of the country. Microsatellites have identified a total of 31 alleles in mandacaru plants, with those from the northeast region showing the lowest polymorphism when compared to their relatives from the south, southeast, and midwest regions (Fernandes et al. 2016).

C. jamacaru is usually found on stony soils, alongside other species of cacti. It is formed by porous pulp cladodes and full of thorns, which bear fruit in the rainiest months, between February and May, and can reach 3-7 m in height (Rocha and Agra 2002). Its fruits have an ovoid shape, with approximately $12 \mathrm{~cm}$ in length, white pulp with numerous black and very small seeds, reminiscent of the pitaya fruit, and are very juicy (Fig. 1). The flowers open only at night, between January
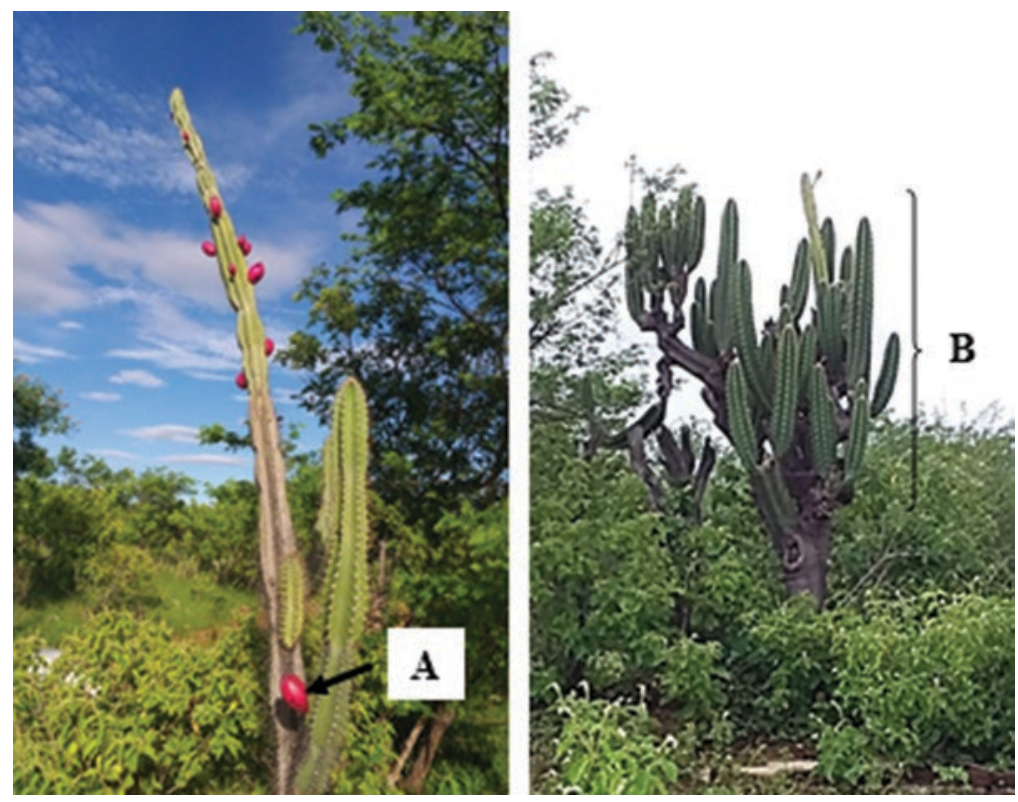

Fig. 1 Pictures of Cereus jamacaru DC. (mandacaru): (A) fruit; (B) cladode (Font: The authors) 
and August, being visited by moths and bats (Rosado and Rosado 1960). Due to their specific morphological and physiological characteristics, they can withstand high temperatures and a long period of drought or low water availability.

\subsection{Popular Use and Possible Application}

Because they are spongy, cacti can store water for long periods, serving as food for animals in times of drought (Sales et al. 2014). Cacti have become popular as ornamental plants in addition to their potential as a source of substances for medicinal, cosmetic, and food use (Biavatti et al. 2007; Park et al. 2001). Human consumption of cactus is reported to have begun in Brazil in the 1980s by groups considered vulnerable, suffering from famine and drought (Santos et al. 2001). Currently, there has been increased interest in studying its nutrients, health effects, and preparation as food products.

Medicinal properties have been attributed to the mandacaru, for example, as infusion for treatment of various diseases, including renal, hepatic, respiratory, stomach, and sinus problems (Agra et al. 2007; Albuquerque et al. 2007; Saraiva et al. 2015; Silva et al. 2014). Other studies have reported the cytotoxic activity of an aqueous extract (non-protein) from the stem (Silva 2015); antibacterial activity of ethanolic extract from the stem (Davet et al. 2009); as well as the purification and characterization of two proteins from C. jamacaru seeds (Aragão et al. 2000; da Costa et al. 2001).

In addition to its medicinal properties, mandacaru is used as fodder in times of drought. Its branches are used in civil construction, to make wooden spoon, doors, windows, boards, and slats, in addition to its wide use as an ornamental plant (Agra et al. 2008; Lucena et al. 2013; Rodrigues and Elesb 2009). The mandacaru has also been cited as a bio-indicator of natural phenomena, its flowering being the sign of a good winter (Lucena et al. 2012).

\subsection{Physical-Chemical Characteristics and Nutritional Composition}

The mandacaru fruit, specifically its pulp, presents in its physical-chemical composition significant values of proteins (1.8-2.35 g/100 g), lipids (1.08-1.98 g/100 g), carbohydrates (9.76-9.86 g/100 g), minerals (0.20-1.30 g/100 g), total soluble solids (TSS; 10.3-14.93 g/100 g), pH (3.73-4.93), titratable acidity (TA; 0.26-0.32 g/100 g), TSS/TA (32.65-50.15), moisture (82.75-90.58 g/100 g), and total phenolic compounds (28.35-326.78 mg EGA/100 g) (Almeida et al. 2009; Bahia et al. 2010; Melo et al. 2017; Moreira et al. 2018; Nascimento et al. 2011; Santos 2018; Santos Neto et al. 2019). These differences may be related to the stage 
of maturation, location, cultivation attributes (such as scarcity of water and soil nutrients), and climatic changes in the year in which the samples used in the aforementioned studies were collected.

A study aiming at the physical-chemical characterization, carried out by our research group with the cladode and the fruit of the mandacaru collected in different regions of the state of Paraíba, Brazil, evaluated the following parameters: $\mathrm{pH}$, molar acidity, moisture, ash, proteins, lipids, insoluble and soluble fiber contents by enzymatic-gravimetric method (AOAC 2016), and total phenolic and flavonoid contents by procedures described by Liu et al. (2002), Sousa et al. (2011), and Zhishen et al. (1999). In vitro antioxidant activity of cladode and fruit of the mandacaru was assessed by an iron reduction method (ferric reducing antioxidant power-FRAP) (Rockenbach et al. 2011) and the ABTS method (Sariburun et al. 2010). Values of the measured physicochemical parameters of cladode and fruit of the mandacaru are presented in Table 1.

Lima (2016), Oliveira et al. (2004), and Sousa et al. (2014) highlight that the pulp of the mandacaru fruit is semi-acidic and low in vitamin $\mathrm{C}(\sim 10 \mathrm{mg} / 100 \mathrm{~g})$, carotenoids $(\sim 0.06 \mathrm{mg} / 100 \mathrm{~g})$, and anthocyanin $(0.23-1.83 \mathrm{mg} / 100 \mathrm{~g})$, having high levels of calcium ( $\sim 58 \mathrm{mg} / 100 \mathrm{~g})$, magnesium $(\sim 238 \mathrm{mg} / 100 \mathrm{~g})$, and potassium $(\sim 136 \mathrm{mg} / 100 \mathrm{~g})$. The small amount of carotenoids and anthocyanins may be related to the presence of other pigments, such as betalains (Lima 2016). Bahia et al. (2010), in a study of the physicochemical characteristics of the mandacaru fruit, identified other carbohydrates in the fruit pulp, such as soluble fibers (pectin $4.36 \%$ ) and

Table 1 Physical-chemical characterization of Cereus jamacaru DC (mandacaru)

\begin{tabular}{|c|c|c|}
\hline \multirow[b]{2}{*}{ Variables } & \multicolumn{2}{|c|}{ Parts of mandacaru } \\
\hline & Cladode & Fruit \\
\hline $\mathrm{pH}$ & $4.88 \pm 0.31$ & $5.03 \pm 0.29$ \\
\hline Molar acidity (g/100 g) & $2.61 \pm 0.50$ & $0.38 \pm 0.25$ \\
\hline Moisture (g/100 g) & $91.86 \pm 0.88$ & $89.70 \pm 0.64$ \\
\hline Ash $(g / 100 g)$ & $1.53 \pm 0.93$ & $0.40 \pm 0.01$ \\
\hline Proteins (g/100 g) & $0.82 \pm 0.25$ & $1.60 \pm 0.17$ \\
\hline Lipids (g/100 g) & $0.74 \pm 0.39$ & $0.60 \pm 0.17$ \\
\hline Total fibers (g/100 g) & $7.24 \pm 1.20$ & $4.13 \pm 0.83$ \\
\hline Soluble fibers $(\mathrm{g} / 100 \mathrm{~g})$ & $4.57 \pm 0.59$ & $1.99 \pm 0.19$ \\
\hline Insoluble fibers $(\mathrm{g} / 100 \mathrm{~g})$ & $2.67 \pm 0.61$ & $2.14 \pm 0.64$ \\
\hline Total phenolic (mg EGA/100 g) $)^{\mathrm{a}}$ & $14.47 \pm 3.10$ & $14.79 \pm 5.54$ \\
\hline $\begin{array}{l}\text { Antioxidant activity - FRAP }(\mu \mathrm{mol} \\
\text { TEAC/g) }\end{array}$ & $0.28 \pm 0.22$ & $0.39 \pm 0.04$ \\
\hline $\begin{array}{l}\text { Antioxidant activity }-\mathrm{ABTS}^{\bullet+}(\mu \mathrm{mol} \\
\left.\mathrm{TEAC}^{\mathrm{g}}\right)^{\mathrm{b}, \mathrm{c}}\end{array}$ & $1.84 \pm 0.56$ & $3.43 \pm 0.57$ \\
\hline
\end{tabular}

Font: The authors

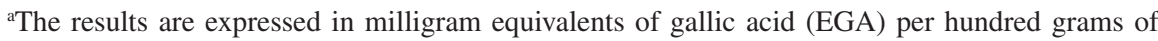
sample (mg EGA/100 g)

${ }^{\mathrm{b}}$ The results are expressed as micromoles of Trolox equivalent antioxidant capacity (TEAC) per hundred grams of sample ( $\mu$ mol TEAC/100 g)

${ }^{\mathrm{c}} \mathrm{ABTS}^{\bullet+}$ cation - 2,2-azino-bis (3-etilbenzo-tiazoline)-6-sulfonic acid 
insoluble fibers (total fibers $0.88 \%$ ), which are important for human health, as these balance the absorption of blood fats, sugar, and cholesterol.

The literature also shows that with regard to antioxidant activities $\left(\mathrm{ABTS}^{+}\right.$and $\mathrm{DPPH})$, the peel of mandacaru fruit in natura presents greater activities $(11.62 \pm 1.34 \mu \mathrm{mol}$ Trolox $/ \mathrm{g}$ and $8.46 \pm 0.90 \mathrm{~g} / \mathrm{g}$ of DPPH, respectively) when compared to the pulp $(9.71 \pm 0.52 \mu \mathrm{mol}$ Trolox $/ \mathrm{g}$ and $6.93 \pm 0.86 \mathrm{~g} / \mathrm{g}$ of DPPH, respectively). Pasteurization processes decrease these activities (Santos et al. 2020). Some studies have revealed the presence of tannins and flavonoids in the cladode and fruit of C. jamacaru (Davet et al. 2009; Dutra et al. 2019; Nascimento et al. 2011), which could be associated with these antioxidant properties in addition to its antiinflammatory, antifungal, and anticancer activities, as well as others.

According to Coelho et al. (2004), the seeds of the mandacaru fruit constitute a significant source of carbohydrates ( $\sim 66 \mathrm{~g} / 100 \mathrm{~g})$, proteins $(\sim 17 \mathrm{~g} / 100 \mathrm{~g})$, and lipids $(\sim 5 \mathrm{~g} / 100 \mathrm{~g})$, with nutritionally interesting levels for food and feed. Mayworm and Salatino (1996) in characterizing the oil extracted from the seeds of C. jamacaru reported that the mandacaru seed oils are rich in unsaturated fatty acids, mainly oleic acid (30.2\%) and linoleic acid (43.4\%), but saturated, palmitic (14.6\%) and stearic $(3.7 \%)$ oils were also found. Further, according to these authors, the composition obtained from mandacaru seeds is similar to that found in soybean oil, which is why this author suggests both species may have common uses.

Silva (2017) evaluating the phytochemical profile and cytotoxic activity of hydroalcoholic extract of $C$. jamacaru DC. by HPLC, FTIR, and UV-VIS observed the absorbance of several metabolites with important therapeutic properties, such as gallic acid, ferrulic acid, caffeine, quercitin, and rutin. In that study, toxicity assessment was performed using Artemia salina cysts, resulting in an LC50 of 1509.17 $\mu \mathrm{g} /$ $\mathrm{mL}$, considered non-toxic, as its LC50 was greater than $1000 \mu \mathrm{g} / \mathrm{mL}$. In addition, cytotoxic activity was analyzed in the cell lines NCI-H292 (pulmonary mucoepidermoid carcinoma), HEp-2 (laryngeal squamous cell carcinoma), MCF-7 (human breast adenocarcinoma), and HL-60 (promyelocytic leukaemia cell). Thus, the extract showed a higher percentage of cell growth inhibition given NCI-H292 cell lines of $24.1 \%$. Hemolytic activity showed a percentage of hemolysis of $3.33 \%$, considered low.

\subsection{Biological Properties}

Mandacaru is a cactaceous symbol of Caatinga vegetation in the Brazilian Northeast region; however, there are few studies about the biological properties of this species. Much of the research with mandacaru is focused on ethnobotanical studies, showing that this cactus is widely used in traditional medicine in the form of teas prepared from the root and used to treat diseases such as rheumatism; wounds; urinary infections; kidney (Albuquerque et al. 2007; Lucena et al. 2013), liver, and respiratory problems; flu; cough; bronchitis; constipation; nausea; vomiting; hypertension (Albuquerque et al. 2007); ovarian cysts; and menstrual regulation (Saraiva et al. 
2015) and to combat scurvy (Paulino et al. 2011; Scheinvar 1985). The mandacaru is also used as a food alternative for animals and humans, especially in the dry season (Lucena et al. 2013; Peron 2011; Rodrigues and Elesb 2009).

Other research has shown that the mandacaru has benefits in the treatment of obesity and has anti-cytotoxic, antitumor, and antioxidant properties, which makes it a matrix with great potential for the development of new drugs (Dutra et al. 2018; Dutra et al. 2019; Medeiros et al. 2019).

Mota et al. (2019) were the first to report the prospecting of proteins of biotechnological importance in different parts of the C. jamacaru (stem, roots, fruit peel, and seed) by enzymatic activities and protease inhibitory activity. Results of this study identified the presence of protease, peroxidase, chitinase, $\beta$-1,3-glucanase, and protease inhibitors, mainly for protein extract of the root. This extract presents significant antifungal activity against the Colletotrichum gloeosporioides, which causes anthracnose in the fruit from several plant species. The inhibitory activity in the vegetative development of the phytopathogen results from morphological alterations in the cell surface, increased permeability in the membrane, and induction of reactive oxygen species, events that culminate in cell death of the fungus. In addition, the research demonstrated that the $C$. jamacaru root extract was able to inhibit the germination of $C$. gloeosporioides spores.

Davet et al. (2009) verified the antibacterial effect of the crude ethanolic extract of wood (EBLE) and the cortex (EBCO) of C. jamacaru against pure colonies of eight pathogenic microorganisms. Further, they showed that EBCO had more pronounced antimicrobial activity than EBCE and that the microorganisms whose growth was most influenced by EBCO were Streptococcus epidermidis, Staphylococcus aureus, Pseudomonas aeruginosa, and Escherichia coli.

It is known that vegetables, including the Cactaceae family, have an autochthonous microbiota and that certain bacteria may have a probiotic effect. The probiotic effect and its benefits on the intestinal health and on the general health status of an individual have been increasingly studied. Allied to this, the demand for foods with functional potential and for non-dairy matrix probiotics has increased over time. In view of the above, our research group has been conducting tests with mandacaru for the following purposes: $(i)$ to isolate and identify native bacteria from the fruit and mandacaru cladode, (ii) to evaluate the probiotic potential of isolated bacteria, (iii) to evaluate the prebiotic and protective potential of the lyophilized cladode on these isolated strains, and ( $i v)$ to ferment the mandacaru fruit with the native microorganisms and to evaluate in vitro bioactive activities of the fermented fruit. For this experiment, 12 collections have been carried out to date, totaling 377 isolates. Of these, 58 isolates passed the gram stain test, assessment for catalase activity, and remained viable for the next stages of the study. Studies of this magnitude are scarce on the subject in question, and the research findings are expected to be of importance. The research that has been carried out with this cactus, especially by our research group, is expected to contribute to the valorization of mandacaru as a source of bioactive compounds with a positive attraction for consumer health. This in turn will stimulate the agroindustrial sector to valorize this matrix as an ingredient with added value for the functional food industry. 
Due to the fiber and phenolic content and, consequently, the antioxidant capacity, mandacaru stands out as a matrix of interest for the development of nutraceutical products that will add functional characteristics and thus increase its market potential. Martins (2018) studied the development of a prebiotic goat yogurt using gelatinous substances from mandacaru and passion fruit (Passiflora edulis Sims) to evaluate their physicochemical characteristics. This gel was found to be in compliance with Brazilian Resolution $\mathrm{n}^{\circ} 12$ of 1978 (Brasil 1978), regarding the relative values for moisture $(10.04 \pm 0.09 \mathrm{~g} / 100 \mathrm{~g})$ and total soluble solids $(65.5 \pm 0.70 \mathrm{~g} / 100 \mathrm{~g})$. In addition, parameters such as $\mathrm{pH}(3.28 \pm 0.04)$, molar acidity $(33.28 \pm 1.31 \mathrm{~g} / 100 \mathrm{~g})$, ash $(0.74 \pm 0.03 \mathrm{~g} / 100 \mathrm{~g})$, and proteins $(0.77 \pm 0.00 \mathrm{~g} / 100 \mathrm{~g})$ showed the potential of the gel being added to other food matrices, such as fermented milk, thus improving and/or adding nutritional and sensory value to these types of food products.

Since 2002, the World Health Organization has stimulated the recuperation of data from plants used in ancient medical practices, as these are considered potentially useful in the development of new drugs (World Health Organization 2002). The American plants were widely used long before the arrival of the Europeans to the continent in the fifteenth century. Besides being one of the richest countries in biodiversity, Brazil is also one of the most diverse in terms of Amerindian culture (Forzza et al. 2012; Neves 2006).

Studies on the mandacaru fruit indicate its potential for exploitation in various technological applications and industrial processes, such as the production of fermented drinks and preparation of dehydrated fruit powder, sweets, jellies, and ice cream (Almeida et al. 2006; Almeida et al. 2011; Moreira et al. 2018; Oliveira et al. 2015; Santos Neto et al. 2019).

Despite this, research on the economic potential of use of mandacaru fruit for food and beverages or its manufacture by agribusiness is scarce. Moreover, there is a need for scientific studies on post-harvest usability, mainly related to enzymatic browning, a limiting factor for valorization in the productive chain of this fruit. This suggests that further studies should be encouraged on the sustainable use of this fruit species in view of its cultural valorization of the Northeast and its contribution of extra resources to the population living in the region, especially in times of drought.

\section{Opuntia ficus-indica (L.) Mill and Nopalea cochenillifera (L.) Salm-Dyck (Palm Species)}

\subsection{Species Characteristics}

The Opuntia ficus-indica (L.) Mill (prickly pear) and Nopalea cochenillifera (L.) Salm-Dyck (cochineal cactus) palm species (Fig. 2) with origins from Mexico are widely cultivated in Brazil as well as in different parts of the world (Nobel 2001). 


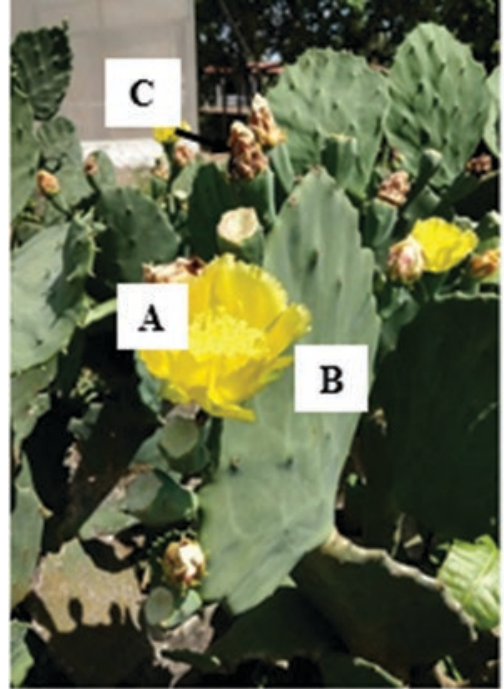

Opuntia ficus-indica (L.) Mill

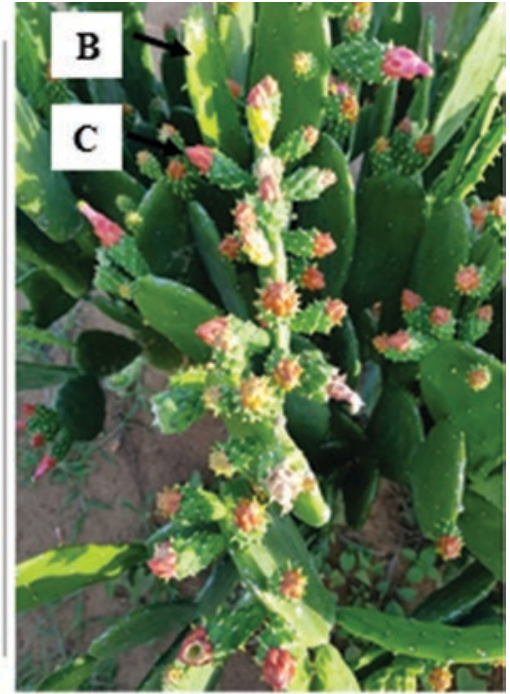

Nopalea cochenillifera (L.) SalmDyck

Fig. 2 Pictures of Opuntia ficus-indica (L) Mill (prickly pear) and Nopalea cochenillifera (L) Salm-Dyck (cochineal cactus). (A) Flower; (B) cladode; (C) fruit (Font: The authors)

They are a species well adapted to the northeastern semiarid region, which is characterized by having shallow, stony, or sandy soils and little organic matter, although the soil is rich in soluble minerals (Oliveira et al. 2011). It is thought that this species was introduced into Brazil because of its property of natural carmine dye, called carminic acid. This dye is biosynthesized by a small insect, the mealybug (Dactylopius sp.), which lives in the cladodes of the plant (Alves et al. 2008; Pessoa 1967).

Regarding botanical classification, forage palms belong to the Cactaceae family, genus Opuntia and Nopalea (Zappi and Taylor 2020). The two most common types of palm that grow in the northeastern region of Brazil differ from each other by their morphological features: the giant or big palm and the small or sweet palm (Lyra et al. 2015).

The giant palm is a variation of that which belongs to the species Opuntia ficusindica. Its cladode ${ }^{1}$ is green-matte and oval-elliptical or sub-oval, can be up to $50 \mathrm{~cm}$ long, and weighs about $1 \mathrm{~kg}$. The flowers are hermaphroditic, medium sized, and bright yellow, and their corolla remains open at maturation. The fruit is an ovoid berry, large, and yellow or purple. The small or sweet palm is a small plant and has a highly branched stem. Its cladode weighs about $350 \mathrm{~g}$ and is almost $25 \mathrm{~cm}$ long, obovate in shape, and bright green. The flowers are red, and their corolla remain half closed during the cycle. The fruit is a purple colored berry. The small or sweet palm

\footnotetext{
${ }^{1}$ Green, flat branch with leaf-like shape and function present in some plants, mainly in cacti.
} 
is considered more palatable and easier to manage because it does not contain spines in its structure, although it has less resistance to drought (da Silva and Santos 2006).

\subsection{Popular Use and Possible Application}

The use as feed for animals in times of drought has been the main use for palm plantations in Brazil (Menezes et al. 2005). In some regions of Brazil and in several other countries in the world, palms are also used for human consumption, where people consume their fruits and young cladodes "nopalitos" as vegetables. In Mexico and in southern USA, palm cultivation is focused on fruit production, although young cladodes are also consumed. The palm fruits are also largely marketed in Europe, being produced and imported from countries around the Mediterranean sea (Moussa-Ayoub et al. 2011; Saenz 2000).

Due to agricultural problems related to the increase in arid zones and the scarcity of water resources, some cacti have gained importance as an effective food source for humans (Shetty et al. 2012; Stintzing and Carle 2005). Therefore, investigations on the chemical components and nutritional values of cactus have become the subject of research in diverse scientific fields (Fernández-López et al. 2010).

\subsection{Physical-Chemical Characteristics and Nutritional Composition}

The chemical composition of forage palm varies according to the species, the cultivation area, and the age of the cladode. The main characteristics of the forage palm are high water, minerals, soluble carbohydrates, and vitamin contents. Palm cladodes are also considered a source of mucilage. Usually, they can be consumed fresh or cooked, and studies have demonstrated the feasibility of processing the cladodes to obtain juice, jellies, gels, liquid sweeteners, pickles, jams, sauces, and other foods (Moussa-Ayoub et al. 2011; Saenz 2000). Data on the composition of O. ficusindica and $N$. cochenillifera are shown in Table 2.

Regarding the constitution of soluble solids, a content of $6.60 \%$ was found for the giant palm and $5.60 \%$ for the small palm. The acidity of the giant palm and small palm was significantly different, with citric acid values of $0.20 \%$ and $0.07 \%$, respectively. The $\mathrm{pH}$ of the giant palm was 4.40 and of the small palm was 4.70 , a significant difference between the two species analyzed (Silva et al. 2015a, b).

The palm cladodes are covered by a cuticle that controls evaporation and allows water to be stored up to 90-93\% of the plant volume (da Silva and Santos 2006). The average values of humidity found in an experiment with the species of giant and small palm were $91.00 \%$ and $89.67 \%$, respectively. Santos et al. (2006) also found high humidity values for the giant palm $(89.80 \%)$ and small palm $(84.60 \%)$. 
Table 2 Physical-chemical composition of Opuntia fícus-indica (giant palm) and Nopalea cochenillifera (small palm)

\begin{tabular}{l|l|l}
\hline Variables & Opuntia fícus-indica & Nopalea cochenillifera \\
\hline Soluble solids (\%) & 6.60 & 5.60 \\
\hline Titratable acidity & 0.20 & 0.07 \\
\hline $\mathrm{pH}$ & 4.40 & 4.70 \\
\hline Humidity (\%) & 91.00 & 89.60 \\
\hline Dry matter (\%) & 9.00 & 10.33 \\
\hline Ash (\%) & 1.19 & 1.17 \\
\hline Calcium (\%) & 6.20 & 7.20 \\
\hline Phosphorus (\%) & 0.13 & 0.10 \\
\hline Total protein (\%) & 0.86 & 0.86 \\
\hline Crude fiber (\%) & 1.65 & 1.37 \\
\hline Reducing sugars (\%) & 1.69 & 1.95 \\
\hline Lipids (\%) & 0.40 & 0.27 \\
\hline
\end{tabular}

Font: (Silva et al. 2015a, b)

Similar to the moisture content, the dry matter contents of the two species also presented different values. Dry matter content was higher for the smaller species, although the ash contents showed no significant difference (Batista et al. 2003). Independent of the genus, palm species have a considerable amount of mineral matter, although these values vary according to the species. Differences might be due to the age of the cladodes, the geographical area, and the time of year when the material was collected. Regarding the levels of calcium, phosphorus, protein, crude fiber, reducing sugars, and lipids, there is no significant difference between species (Santos et al. 2006; Viana et al. 2014).

The palms are also important because of their high mucilage content. Mucilage is mainly composed of galactose, mannose, xylose, and other sugars. Therefore, it has a high capacity to retain water, like pectins and some algae polysaccharides. Due to this high water absorption capacity, mucilage can be used in food, cosmetics, and pharmaceutical products where it dissolves, disperses, and forms colloids (DelValle et al. 2005). The density obtained for the mucilage of the $N$. cochenillifera is comparable to that reported for the same concentrations of arabic gum (Tahir et al. 2007). Indeed, several cultures have traditionally used the cladodes of O. ficusindica and $N$. cochenillifera as an important ingredient for cooking. Its characteristics of density, viscosity, $\mathrm{pH}$, and conductivity fit the recommendations for use as an additive in the food and medicine formulations. Therefore, the mucilage from the palm can be considered a good alternative emulsifier and stabilizer.

No less important than the cladode, the fruit of the palm is a berry with many pleasant-tasting seeds, which facilitates its inclusion in human diets. Moreover, it presents readily absorbable sugars, high vitamin C content $(12.7 \mathrm{mg} / 100 \mathrm{~g})$, $\beta$-carotene $(12.9 \mu \mathrm{g} / 100 \mathrm{~g})$, minerals, polyphenols, and amino acids (Stintzing et al. 2001). The palm fruit, considered a source of nutrients and vitamins in some 
countries, is processed together with some products such as sweets, alcoholic drinks, and additives (Karababa et al. 2014; Kinupp and Lorenzi 2014; SáenzHernández 2001).

Palms can be considered an effective alternative to fight hunger and sub nutrition in the northeastern semiarid region, as they are rich in vitamins $\mathrm{A}, \mathrm{B}$, and $\mathrm{C}$ and in minerals, such as calcium, magnesium, sodium, and potassium, and have 17 types of amino acids. Comparatively, palm has greater nutritional value than foods such as cabbage, beets, and bananas, in addition to their economic advantage. The palm is commonly consumed in juices and salads and in stewed and cooked foods (FloresValdez 2001; Kinupp and Lorenzi 2014; Sáenz-Hernández 2001). In some regions, the high resistance to the consumption of palm as a food for humans is due to prejudice, since the traditional use of the plant is to feed animals (Nunes 2011).

Furthermore, there is a growing interest in the use of palms other than for food. Traditional medicine has recognized some benefits attributed to the use of these species, as they have traditionally been used to treat urinary problems and hypertension (Lans 2006). There are reports about the consumption of palm for treating diabetes (Andrade-Cetto and Heinrich 2005; Lans 2006). Some people use thin slices of cladodes on burned skin or on swelling, similar to the use of other species such as aloe vera (Aloe sp.) (Hoffmann 2001).

\subsection{Biological Properties}

Some studies have also demonstrated pharmacological uses of these species. The gastroprotective activity of mucilages and pectins extracted from $O$. ficus-indica cladodes was tested by three different in vivo ulcer models induced by ethanol in rats (Galati et al. 2002a, 2007; Vázquez-Ramírez et al. 2006). The in vivo study by Hwang et al. (2017) suggests that the aqueous extract of $O$. ficus-indica can be used to prevent and/or control blood glucose levels; therefore, it is a potential dietary supplement. Another in vitro and in vivo study also showed that the O. ficus-indica extract improved hyperglycemia, hyperinsulinemia, and glucose tolerance due to augmented pancreatic function caused by the increase in $\beta$-cell mass (Leem et al. 2016). In the same context, a pilot clinical trial was conducted with Mexican patients in order to verify the effects of a drink based on $N$. cochenillifera (Fabela-Illescas et al. 2015). The studies by Trombetta et al. (2006) evaluated the healing potential of two lyophilized polysaccharide extracts obtained from $O$. ficus-indica cladodes in induced wounds in rats. The authors concluded that the hygroscopic, rheological, and viscoelastic properties of these polysaccharides may be essential to promote healing. Mouhaddach et al. (2017) reported on the analgesic activity of O. ficusindica extracts obtained by decoction carried out in hot plate and tail movement of in vivo models.

Potential diuretic (Galati et al. 2002b), antioxidant, anti-inflammatory (Ammar et al. 2018; Benayad et al. 2014; Matias et al. 2014; Necchi et al. 2011), 
antimicrobial, and antiviral activities (Bargougui et al. 2019; Gomez-Flor et al. 2006) were also attributed to these species in nonclinical studies.

The pharmacological potential of the palms is generally related to the presence of components already identified in these species. These are primarily phenolic compounds such as quinic acid, gallic acid, protocatechuic acid, syringic acid, derivatives of hydroxycinnamic acid, and flavonoids as isorhamnetin, quercetin, naringenin, luteolin, apigenin, kaempferol, cirsiliol, nicotiflorin, and rutin (Belhadj Slimen et al. 2017; De Leo et al. 2010; Guevara-Figueroa et al. 2010; MoussaAyoub et al. 2011).

Taken together, most studies conclude that the species $O$. ficus-indica and $N$. cochenillifera exhibit nutritional, economic, and pharmacological potential. Nonclinical and clinical trials have been carried out in an attempt to explore, identify, and test new bioactive and pharmacological activities of these species.

\section{Pilosocereus gounellei (Xique-xique)}

\subsection{Species Characteristics}

Pilosocereus gounellei (A. Weber ex K. Schum. Bly. ex Rowl), popularly known as the xique-xique (Fig. 1a), is a species of the Cactaceae family, belonging to the subfamily Cactoideae, of the genus Pilosocereus Byles \& Rowley (Dias et al. 2015), exclusively found in Brazilian Caatinga (Oliveira et al. 2018). Its occurrence has been confirmed in the northeast part of Brazil, in Alagoas, Bahia, Ceará, Maranhão, Paraíba, Pernambuco, Piauí, Rio Grande do Norte, and Sergipe (Zappi et al. 2015).

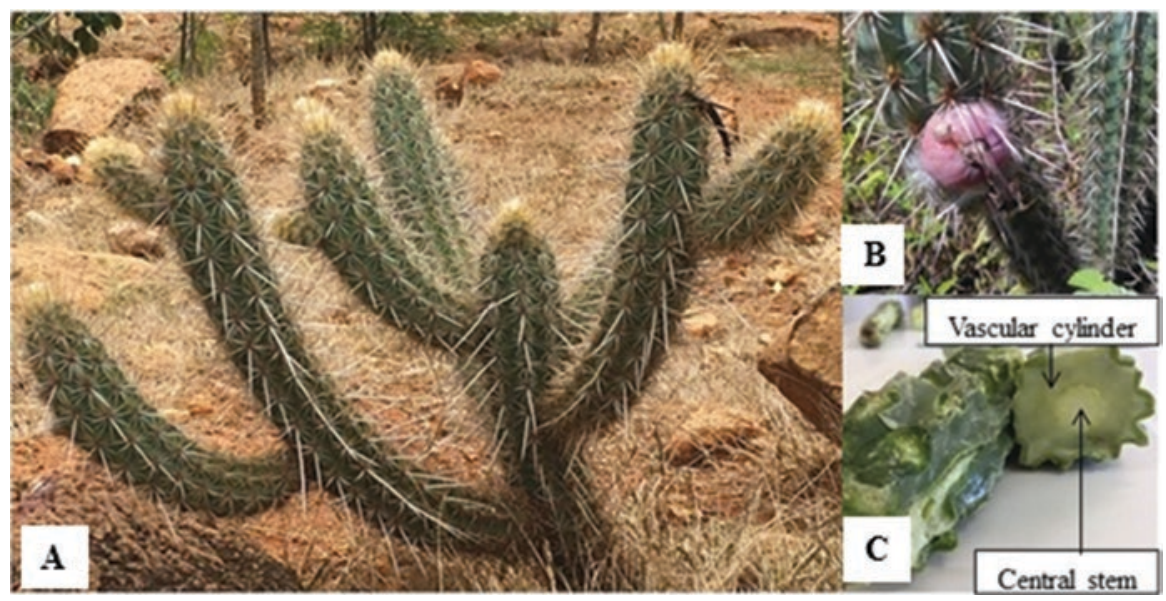

Fig. 3 Pilosocereus gounellei (xique-xique). (A) Xique-xique. (B) Fruit. (C) Cladode (Font: The authors) 
This cactaceous grows in dry areas of the semiarid northeast region and shallow soils and on rocks and multiplies regularly, covering large areas of Caatinga. It has an erect trunk with wide lateral branches, gently describing a wide curve upward, its branches composed of large thorns, skin an opaque green color (Fig. 3a), white tubular flowers (Cavalcanti and Resende 2007), and fruits reddish, rounded berries with small seeds (Fig. 3b) (Almeida et al. 2007). The cladodes of xique-xique can be divided into vascular cylinder and central stem (Fig. 3c).

\subsection{Popular Use and Possible Application}

The xique-xique is a natural resource that makes an important contribution to the livelihood of local populations in the semiarid region of northeastern Brazil (Monteiro et al. 2015). It has been used as animal food, human food, human medicine, and veterinary medicine, besides serving for construction, as ornament, in personal hygiene, as bio-indicator of rain when blooming, and in technology, among other uses (Silva 2015) (Table 3).

The use of xique-xique in food has been reported in a number of studies. In addition to the consumption of its in natura fruit (Lucena et al. 2015), the pulp extracted from the stem of xique-xique has been used in the elaboration of different products, such as cocada, other candies, flour, and couscous (Almeida et al. 2007; Lucena et al. 2013). The dried and powdered pulp can be incorporated into wheat for the preparation of bakery products (Almeida et al. 2007). The flour to prepare the couscous can be produced from the cladode and can be consumed cooked or roasted (Nascimento et al. 2012).

In addition to the nutritional potential of xique-xique, popular knowledge about this species involves its medicinal use. Xique-xique parts such as stems, roots, and flowers are popularly used to treat constipation (Lucena et al. 2015), gastritis (Lucena et al. 2012), as well as urethra inflammation (Roque et al. 2010), prostate inflammation, hypoglycemia, injuries (Agra et al. 2008; Albuquerque et al. 2007), and jaundice (Albuquerque et al. 2007).

\subsection{Physical-Chemical Characteristics and Nutritional Composition}

When evaluating the physical and chemical characteristics of the xique-xique, it was observed that the vascular cylinder and the central stem of the xique-xique branches presented, respectively, soluble solids (1.50 and $\left.1.50{ }^{\circ} \mathrm{Brix}\right), \mathrm{pH}$ (4.66 and $5.18)$, ash (1.38\% and $1.34 \%)$, ascorbic acid $(0.33 \%$ and $0.25 \%)$, total solids $(5.83 \%$ and $13.96 \%$ ), and insoluble solids (3.61\% and $2.98 \%)$. This leads to the conclusion that the central stem is more suitable for the production of flour, and the vascular 
Table 3 Description of popular use and possible application of Pilosocereus gounellei (xique-xique)

\begin{tabular}{|c|c|c|c|c|}
\hline Purposes & Part used & Mode of use & Medicinal use & References \\
\hline \multirow[t]{3}{*}{ Human feed } & Fruit & In natura & - & $\begin{array}{l}\text { Lucena et al. } \\
(2015) \\
\text { Machado et al. } \\
(2018)\end{array}$ \\
\hline & Pulp & $\begin{array}{l}\text { Roasted or baked } \\
\text { (cookies, cakes, } \\
\text { cocada, sweets, flour, } \\
\text { couscous) }\end{array}$ & - & $\begin{array}{l}\text { Almeida et al. } \\
\text { (2007) } \\
\text { Nascimento } \\
\text { et al. (2012) } \\
\text { Lucena et al. } \\
(2013) \\
\text { Machado et al. } \\
(2018)\end{array}$ \\
\hline & Pulp & $\begin{array}{l}\text { Dried and converted } \\
\text { into powder } \\
\text { (incorporated into } \\
\text { wheat for use in } \\
\text { baking) } \\
\end{array}$ & - & $\begin{array}{l}\text { Almeida et al. } \\
(2007)\end{array}$ \\
\hline \multirow[t]{3}{*}{ Animal feed } & Fruit & In natura & \multirow[t]{3}{*}{-} & \multirow{3}{*}{$\begin{array}{l}\text { Bravo Filho } \\
\text { et al. (2018) } \\
\text { Lucena et al. } \\
(2015) \\
\text { Machado et al. } \\
(2018)\end{array}$} \\
\hline & Branch & \multirow[t]{2}{*}{ Cut or burned } & & \\
\hline & Entire plant & & & \\
\hline \multirow[t]{7}{*}{$\begin{array}{l}\text { Human } \\
\text { medicine }\end{array}$} & $\begin{array}{l}\text { Mucilage } \\
\text { (aquifer } \\
\text { parenchyma) }\end{array}$ & \multirow[t]{2}{*}{-} & \multirow[t]{2}{*}{$\begin{array}{l}\text { To remove thorns } \\
\text { from the skin }\end{array}$} & \multirow[t]{2}{*}{$\begin{array}{l}\text { Lucena et al. } \\
\text { (2015) }\end{array}$} \\
\hline & Pulp & & & \\
\hline & Fruit & In natura & Constipation & $\begin{array}{l}\text { Lucena et al. } \\
(2015)\end{array}$ \\
\hline & Pulp & $\begin{array}{l}\text { Soak and drink the } \\
\text { water }\end{array}$ & Gastritis & \begin{tabular}{|l}
$\begin{array}{l}\text { Lucena et al. } \\
(2012)\end{array}$ \\
\end{tabular} \\
\hline & Root & Macerate & Urethra inflammation & $\begin{array}{l}\text { Roque et al. } \\
(2010)\end{array}$ \\
\hline & Root & Decoction & Prostate inflammation & $\begin{array}{l}\text { Agra et al. } \\
(2008)\end{array}$ \\
\hline & $\begin{array}{l}\text { Stem, root, } \\
\text { and flowers }\end{array}$ & - & $\begin{array}{l}\text { Prostate } \\
\text { inflammation, } \\
\text { jaundice, } \\
\text { hypoglycemia, and } \\
\text { injuries }\end{array}$ & $\begin{array}{l}\text { Albuquerque } \\
\text { et al. (2007) }\end{array}$ \\
\hline $\begin{array}{l}\text { Veterinary } \\
\text { medicine }\end{array}$ & Mucilage & - & $\begin{array}{l}\text { Used on animal } \\
\text { wounds }\end{array}$ & $\begin{array}{l}\text { Lucena et al. } \\
(2013,2015)\end{array}$ \\
\hline
\end{tabular}


Table 3 (continued)

\begin{tabular}{l|l|l|l|l}
\hline Purposes & Part used & Mode of use & Medicinal use & References \\
\hline Ornament & Entire plant & Gardens and backyards & - & $\begin{array}{l}\text { Lucena et al. } \\
(2013,2015) \\
\text { Machado et al. } \\
(2018) \\
\text { Bravo Filho } \\
\text { et al. (2018) }\end{array}$ \\
\hline $\begin{array}{l}\text { Personal } \\
\text { hygiene }\end{array}$ & Pulp & Shampoo & - & $\begin{array}{l}\text { Lucena et al. } \\
(2013)\end{array}$ \\
\hline Bio-indicator & Flower & Rain indicator & - & $\begin{array}{l}\text { Lucena et al. } \\
(2015)\end{array}$ \\
\hline Technology & Thorns & $\begin{array}{l}\text { "needles" } \\
\text { (Making lace) }\end{array}$ & - & $\begin{array}{l}\text { Lucena et al. } \\
(2012)\end{array}$ \\
\hline Shadow & Entire plant & - & - & $\begin{array}{l}\text { Machado et al. } \\
\text { (2018) }\end{array}$ \\
\hline Construction & Entire plant & Hedge & - & $\begin{array}{l}\text { Lucena et al. } \\
\text { (2015) } \\
\text { Bravo Filho } \\
\text { et al. (2018) }\end{array}$ \\
\hline Construction & Mucilage & Surface treatment & - & $\begin{array}{l}\text { Nobréga } \\
\text { (2019) }\end{array}$ \\
\hline
\end{tabular}

Table 4 Physical-chemical characterization of Pilosocereus gounellei (xique-xique)

\begin{tabular}{l|c|c}
\hline \multirow{2}{*}{ Variables } & Xique-xique cladodes & \\
\cline { 2 - 3 } & Vascular cylinder & Central stem \\
\hline Moisture $(\mathrm{g} / 100 \mathrm{~g})$ & $94.16 \pm 0.99$ & $87.13 \pm 1.64$ \\
\hline Acidity $(\mathrm{g} / 100 \mathrm{~g})$ & $0.07 \pm 0.01$ & $0.09 \pm 0.02$ \\
\hline $\mathrm{pH}$ & $4.77 \pm 0.21$ & $4.87 \pm 0.21$ \\
\hline Ash $(\mathrm{g} / 100 \mathrm{~g})$ & $1.99 \pm 0.04$ & $1.59 \pm 0.00$ \\
\hline Proteins $(\mathrm{g} / 100 \mathrm{~g})$ & $0.49 \pm 0.00$ & $0.76 \pm 0.01$ \\
\hline Lipids $(\mathrm{g} / 100 \mathrm{~g})$ & $0.28 \pm 0.00$ & $0.77 \pm 0.04$ \\
\hline Total fiber $(\mathrm{g} / 100 \mathrm{~g})$ & $2.70 \pm 0.01$ & $6.54 \pm 0.01$ \\
\hline Insoluble fiber $(\mathrm{g} / 100 \mathrm{~g})$ & $1.83 \pm 0.00$ & $5.18 \pm 0.05$ \\
\hline Soluble fiber $(\mathrm{g} / 100 \mathrm{~g})$ & $0.87 \pm 0.01$ & $1.37 \pm 0.04$ \\
\hline TSS $\left({ }^{\circ} \mathrm{Brix}\right)$ & $2.00 \pm 0.42$ & $2.71 \pm 0.23$ \\
\hline Fructose $(\mathrm{g} / 100 \mathrm{~g})$ & $0.31 \pm 0.02$ & $1.07 \pm 0.02$ \\
\hline Glucose $(\mathrm{g} / 100 \mathrm{~g})$ & $0.14 \pm 0.02$ & $0.54 \pm 0.01$ \\
\hline Xylose $(\mathrm{g} / 100 \mathrm{~g})$ & $0.06 \pm 0.01$ & $0.37 \pm 0.02$ \\
\hline Arabinose $(\mathrm{g} / 100 \mathrm{~g})$ & $0.06 \pm 0.01$ & $0.20 \pm 0.01$ \\
\hline Potassium $(\mathrm{mg} / 100 \mathrm{~g})$ & $308.4 \pm 3.65$ & $101.6 \pm 1.65$ \\
\hline Magnesium $(\mathrm{mg} / 100 \mathrm{~g})$ & $182.40 \pm 2.10$ & $167.10 \pm 4.11$ \\
\hline
\end{tabular}

Font: (Bezerril 2017) 
cylinder is more appropriate for the production of products with a high water content (Almeida et al. 2007).

Preliminary studies on the xique-xique cladodes have reported high water content, soluble and insoluble fibers, and high values of minerals, especially potassium, magnesium, and calcium in the vascular cylinder. The presence of fructose, glucose, xylose, and arabinose was also found as the main constituents (Bezerril 2017) (Table 4).

The stem of $P$. gounellei contains an anionic trypsin inhibitor stable to $50{ }^{\circ} \mathrm{C}$ and active on medically important bacteria; the yeast, Candida krusei, may lessen the use of antibiotics and thus contribute to reduce the problem of antibiotic resistance. Outcomes reported have revealed new insights into the biochemistry of $P$. gounellei, increasing the biotechnological value of this plant (Rocha Filho et al. 2019).

Flours (Fig. 4a) developed from the central stem of xique-xique have a high content of soluble and insoluble fibers, resistant starch, and minerals, mainly calcium, iron, potassium, magnesium, and manganese. In addition, the plant has high viscosity and gel texture, indicating a potential for use as a thickening or gelling agent in food. In addition, the flours had compounds with antioxidant activity and few antinutritional factors. Cookies (Fig. 4b) made from the flour of this plant also proved to be rich in fibers and minerals. In sensory terms, they were tasty and well received by consumers (Machado 2019).
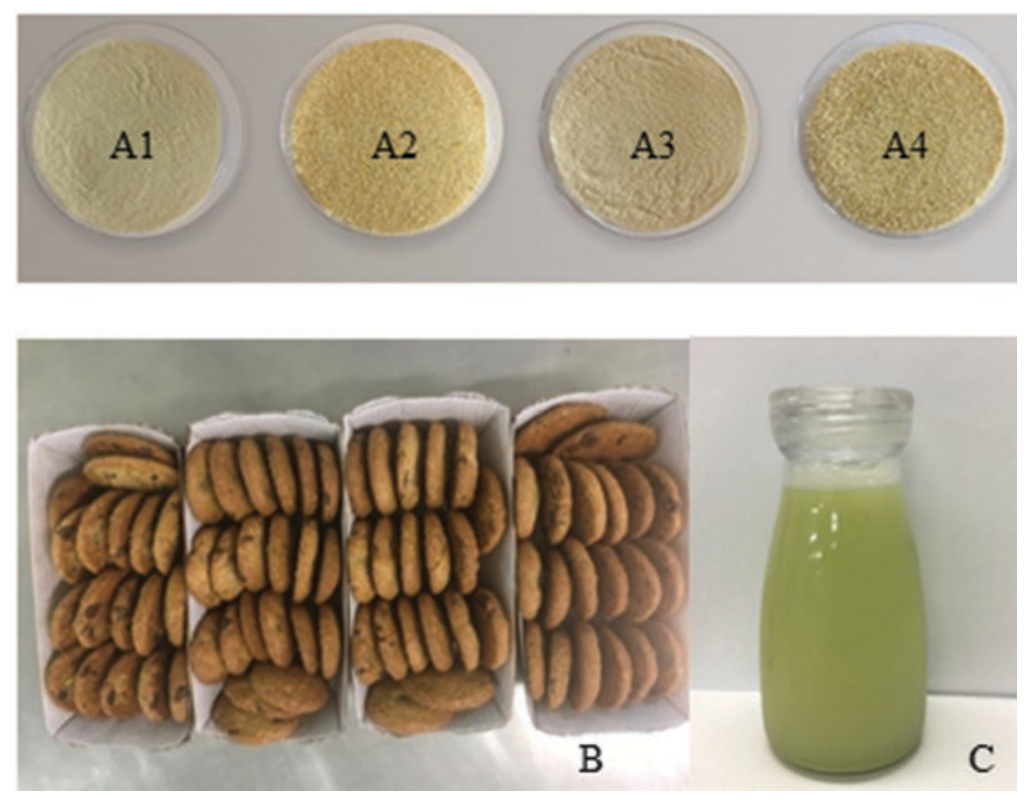

Fig. 4 Products made from Pilosocereus gounellei (xique-xique). (Font: The authors) Legend: (A1) Fresh xique-xique flour (100 mesh); (A2) natural xique-xique flour (28 mesh); (A3) autoclaved xique-xique flour (100 mesh); (A4) xique-xique autoclaved flour (28 mesh); (B) xiquexique cookie (100 mesh); (C) xique-xique Juice 
Several genera of the Cactaceae family have bioactive compounds in their composition (Agostini-Costa 2020). The xique-xique contained triterpenes and phenolic compounds (Almeida et al. 2005), flavonoids (Nascimento et al. 2012), and catechin and epigallocatechin gallate, in addition to other compounds belonging to the group of phenolic acids and procyanidins (Bezerril 2017).

Xique-xique fruits contain various functional compounds, such as phenolic compounds and betalains, which provided high antioxidant activity, with potential for adding value (da Silva et al. 2018). A study isolated and identified ten compounds of Pilosocereus gounellei: pinostrobin, $\beta$-sitosterol, a mixture of $\beta$-sitosterol/stigmasterol, 132-hydroxyphaeophytin a, phaeophytin a, sitosterol 3-O- $\beta$-Dglucopyranoside/stigmasterol 3-O- $\beta$-D-glucopyranoside, kaempferol, quercetin, $7^{\prime}$-ethoxy-trans-feruloyltyramine, and trans-feruloyltyramine. In addition, same authors have demonstrated that the fruit ethanol extract possesses excellent antioxidant activity, mainly because of the presence of phenolic compounds reported in the genus and the Cactaceae family (Maciel et al. 2015).

The juice (Fig. 4c) made from the xique-xique cladode showed high fiber content, mainly soluble, as well as a variety of phenolic compounds, such as catechin, epicatechin, epicatechin gallate, epigallocatechin gallate, quercetin 3-glucoside, rutin, kaempferol 3-glucoside, gallic acid, caffeic acid, syringic acid, chlorogenic acid, naringenin, and hesperidin (Assis et al. 2019). In addition, the xique-xique juice induced a selective and intense fermentable activity to different probiotic Lactobacillus isolates, similar to the effects caused by fructooligosaccharide (FOS), a well-known prebiotic ingredient. This suggests that xique-xique juice could have prebiotic properties, adding value to an unconventional and still little exploited plant food as a source of bioactive compounds (Ribeiro et al. 2020).

Despite few existing studies, research has revealed the great potential of the whole of $P$. gounellei. This provides an enormous advantage due to the low residue generated and the infinite areas the plant may be used, which range from the pharmaceutical industry to the food industry.

\subsection{Biological Properties}

In view of the traditional use of xique-xique by the population, biological studies have been carried out to validate its effects on health. The crude ethanol extract of the stems of xique-xique has been reported to have low toxicity, exhibiting antiinflammatory activity at a dose of $25 \mathrm{mg} / \mathrm{kg}$ over 4 hours as evaluated by the carrageenan-induced paw edema model in rats (Dias et al. 2015).

The administration of the ethanol extracts of root and cladodes of the xiquexique had an important gastroprotective effect, due to the inhibition of the formation of gastric lesions in animal models, without promoting toxic effects (Sousa et al. 2018).

The saline extract from the stem of xique-xique containing flavonoids and reducing sugars demonstrated antinociceptive activity, without showing toxicity or 
altering motor coordination in mice (Oliveira et al. 2018). In addition, the saline extract from the stem of $P$. gounellei did not present significant toxic effects over 28 consecutive days and demonstrated antipyretic activity, together with hypoglycemic and hypolipidemic effects (Oliveira et al. 2019). Still, when administered orally at the tested doses, the extract is genotoxically safe, when used with caution in doses above $1.000 \mathrm{mg} / \mathrm{kg}$, and has a protective effect against CPA-induced DNA damage (Oliveira et al. 2020).

The ingestion of xique-xique cladode juice had a protective effect on intestinal inflammation and showed a decrease in pro-inflammatory markers and oxidative stress in an animal model of inflammatory bowel disease. These effects were attributed to the phenolic compounds and fibers present in the juice (Assis et al. 2019).

\section{Final Considerations}

This chapter has shown that the uses of cacti have gained prominence in several areas, especially as a food for human consumption and for pharmacological use, making cacti of interest in reducing hunger and fighting diseases. We have highlighted the diversity of nutrients in cladodes and in fruits, used for fresh consumption, in elaborated preparations, or even in extracts such as herbal medicines. The need for further experimental and clinical research on these plants is highlighted in order to elucidate their toxicity related to health considerations. The use of cacti is important for the restoration and conservation of the Caatinga's biodiversity, the development of local culture, and the promotion of food and nutritional security, especially in the northeast part of Brazil.

\section{References}

Agostini-Costa TS (2020) Bioactive compounds and health benefits of Pereskioideae and Cactoideae: a review. Food Chem 327:126961. https://doi.org/10.1016/j.foodchem.2020.126961

Agra M, Baracho G, Nurit K et al (2007) Medicinal and poisonous diversity of the flora of "Cariri Paraibano", Brazil. J Ethnopharmacol 111:383-395. https://doi.org/10.1016/j.jep.2006.12.007

Agra MF, Silva KN, Lima J et al (2008) Survey of medicinal plants used in the region Northeast of Brazil. Braz J Pharmacogn 18:472-508

Albuquerque UP, de Medeiros PM, de Almeida ALS et al (2007) Medicinal plants of the Caatinga (semi-arid) vegetation of NE Brazil: a quantitative approach. J Ethnopharmacol 114:325-354. https://doi.org/10.1016/j.jep.2007.08.017

Almeida C, Lima e Silva T, Amorim E et al (2005) Life strategy and chemical composition as predictors of the selection of medicinal plants from the Caatinga (Northeast Brazil). J Arid Environ 62:127-142. https://doi.org/10.1016/j.jaridenv.2004.09.020

Almeida MM, Passos D, De Almeida TS et al (2006) Cinética da produção do fermentado do fruto do mandacaru. Rev Bras Prod Agroindustriais 8:35-42

Almeida C, Figueirêdo R, Queiroz A, Oliveira F (2007) Physical and chemical characteristics of xiquexique pulps. Rev Cien Agron 38:440-443 
Almeida M, Silva F, Conrado L et al (2009) Physical and physical-chemical characterization of mandacaru fruits. Rev Bras Prod Agro 11:15-20

Almeida MM, Luiz F, Da Silva H et al (2011) Revista verde de agroecologia e desenvolvimento sustentável Grupo Verde de Agricultura Alternativa (GVAA) estudo cinético e caracterização da bebida fermentada do Cereus jamacaru P. DC. Rev Verde Agroecol Desenvolv Sustent 6:176-183

Alves A, De Souza M, Carla A et al (2008) Fruto de palma [Opuntia fícus-indica (L) Miller, Cactaceae]: morfologia, compocicão química, fisiologia, índices de colheita e fisiologia póscolheita. Rev Iberoam Tecnol Postcosecha 9:16-25

Ammar I, Ben Salem M, Harrabi B et al (2018) Anti-inflammatory activity and phenolic composition of prickly pear (Opuntia ficus-indica) flowers. Ind Crop Prod 112:313-319. https://doi. org/10.1016/j.indcrop.2017.12.028

Anderson E (2001) The cactus family. Timber Press, Portland

Andrade C, Marques JGW, Zappi DC (2006) Utilização de cactáceas por sertanejos baianos. Tipos conexivos para definir categorias utilitárias. Sitientibus 6:3-12

Andrade-Cetto A, Heinrich M (2005) Mexican plants with hypoglycaemic effect used in the treatment of diabetes. J Ethnopharmacol 99:325-348. https://doi.org/10.1016/j.jep.2005.04.019

Aragão T, Souza P, Uchôa A et al (2000) Characterization of a methionine-rich protein from the seeds of Cereus jamacaru Mill. (Cactaceae). Braz J Med Biol Res 33:897-903. https://doi. org/10.1590/S0100-879X2000000800005

Assis POA, Guerra GCB, Araújo DF et al (2019) Intestinal anti-inflammatory activity of xiquexique (Pilosocereus gounellei A. Weber ex K. Schum. Bly. Ex Rowl) juice on acetic acidinduced colitis in rats. Food Funct 10:7275-7290. https://doi.org/10.1039/C9FO00920E

Association Official Analytical Chemists AOAC (2016) Methods of analysis of AOAC international, 20th edn. AOAC International, Rockville

Bahia E, Morais L, Silva M, et al (2010) Estudo das Características físico-químicas do fruto do mandacaru (Cereus jamacaru P.DC.) cultivado no sertão pernambucano. In: VIII SEMEALI

Bargougui A, Maatoug Tag H, Bouaziz M, Triki S (2019) Antimicrobial, antioxidant, total phenols and flavonoids content of four cactus (Opuntia ficus-indica) cultivars. Biomed Pharmacol J 12:1353-1368. https://doi.org/10.13005/bpj/1764

Barthlott W, Hunt DR (1993) Cactaceae. Springer Berlin Heidelberg, Berlin, Heidelberg

Batista AM, Mustafa AF, McAllister T et al (2003) Effects of variety on chemical composition, in situ nutrient disappearance and in vitro gas production of spineless cacti. J Sci Food Agric 83:440-445. https://doi.org/10.1002/jsfa.1393

Belhadj Slimen I, Mabrouk M, Hanene C, Najar TT (2017) LC-MS analysis of phenolic acids, flavonoids and Betanin from spineless Opuntia ficus-indica fruits. Cell Biol 5:17. https://doi. org/10.11648/j.cb.20170502.12

Benayad Z, Martinez-Villaluenga C, Frias J et al (2014) Phenolic composition, antioxidant and anti-inflammatory activities of extracts from Moroccan Opuntia ficus-indica flowers obtained by different extraction methods. Ind Crop Prod 62:412-420. https://doi.org/10.1016/j. indcrop.2014.08.046

Bezerril FF (2017) Caracterização nutricional e de compostos bioativos do Xique-Xique (Pilosocereus gounellei (A. Weber ex. K. Schum.) Bly. ex Rowl.). Dissertation, Federal University of the Paraíba

Bhandari MM (1974) Famine foods in the Rajasthan desert. Econ Bot 28:73-81. https://doi. org/10.1007/BF02861383

Biavatti MW, Marensi V, Leite SN, Reis A (2007) Ethnopharmacognostic survey on botanical compendia for potential cosmeceutic species from Atlantic Forest. Rev Bras Farmacogn 17:640-653. https://doi.org/10.1590/S0102-695X2007000400025

Brasil (1978) Resolução Normativa nº 15 de 4 de maio de 1978. Ministério da Saúde. Secretaria de Vigilância Sanitária.

Brasil (2010) Manual de Hortaliças Não convencionais. Ministério da Agricultura. Pecuária e Abastecimento, Brasília, p 92 
Bravo Filho ES, de Santana MC, Santos PAA, Ribeiro AS (2018) Levantamento etnobotânico da família Cactaceae no estado de Sergipe. Rev Fitos 12:41-53. https://doi. org/10.5935/2446-4775.20180005

Cavalcanti N, Resende G (2007) Consumo de xiquexique (Pilocereus gounellei (A. Weber ex K. Schum.) Bly. ex Rowl) por caprinos no Semi-Árido da Bahia. Rev Caatinga 20:22-27

Coelho R, Ferreira Neto C, Figuerêdo R (2004) Avaliação química de sementes de mandacaru (Cereus jamacaru P. DC.). In: XXIX Congresso Brasileiro de Ciência e Tecnologia de Alimentos. Recife, Brazil

da Costa IR, de Souza PAS, Bloch C Jr et al (2001) Isolation and characterisation of a reserve protein from the seeds of Cereus jamacaru (Cactaceae). Braz Arch Biol Technol 44:331-335. https://doi.org/10.1590/S1516-89132001000400002

da Silva CCF, Santos LC (2006) Palma Forrageira (Opuntia Fícus- Indica Mill) como alternativa na alimentação de ruminantes (Forage Palm (Opuntia Fícus- Indica Mill) as alternative in ruminant feeding). Redvet 7:1-11

da Silva AA, Dantas RL, Véras CDS et al (2018) Physical and physicochemical characteristics, bioactive compounds and antioxidant activity of xiquexique (Pilosocereus gounellei (A. Weber ex K. Schum.)) fruit. Semin Ciências Agrárias 39:1969. https://doi. org/10.5433/1679-0359.2018v39n5p1969

Davet A, Virtuoso S, Dias JFG et al (2009) Atividade antibacteriana de Cereus jamacaru DC, Cactaceae. Rev Bras Farmacogn 19:561-564. https://doi.org/10.1590/ S0102-695X2009000400009

De Leo M, De Abreu MB, Pawlowska AM et al (2010) Profiling the chemical content of Opuntia ficus-indica flowers by HPLC-PDA-ESI-MS and GC/EIMS analyses. Phytochem Lett 3:48-52. https://doi.org/10.1016/j.phytol.2009.11.004

Del-Valle V, Hernández-Muñoz P, Guarda A, Galotto MJ (2005) Development of a cactus-mucilage edible coating (Opuntia ficus indica) and its application to extend strawberry (Fragaria ananassa) shelf-life. Food Chem 91:751-756. https://doi.org/10.1016/j.foodchem.2004.07.002

Dias G, Guedes E, Maciel J et al (2015) Acute oral toxicity and anti-inflammatory activity of ethanolic extract from Pilosocereus gounellei (Fac Weber) in rats. Int J Pharmacogn Phytochem Res 7:1-6

Dutra JV, Moisés Ferreira J, Costalonga Pereira P et al (2018) Cereus jamacaru D.C. Hydroalcoholic extract promotes anti-cytotoxic and antitumor activity. Pharmaceuticals 11:1-18. https://doi. org/10.3390/ph11040130

Dutra JV, de Oliveira J-H, dos Santos V et al (2019) Fruiting increases total content of flavonoids and antiproliferative effects of Cereus jamacaru D.C. cladodes in sarcoma 180 cells in vitro. Asian Pac J Trop Biomed 9:66-72. https://doi.org/10.4103/2221-1691.250857

Fabela-Illescas HE, Ávila-Domínguez R, Hernández-Pacheco A et al (2015) Efecto de una bebida a base de nopal (Nopalea cochenillifera (1) Salm-dyck) en pacientes de una población rural de Hidalgo, México; ensayo clínico piloto. Nutr Hosp 32:2710-2714. https://doi.org/10.3305/ nh.2015.32.6.9762

Fernandes VN, das Neves AF, Martin PG et al (2016) Genetic structure and molecular divergence among samples of mandacaru (Cereus spp.; Cactaceae) as revealed by microsatellite markers. Biochem Syst Ecol 64:38-45. https://doi.org/10.1016/j.bse.2015.11.003

Fernández-López JA, Almela L, Obón JM, Castellar R (2010) Determination of antioxidant constituents in cactus pear fruits. Plant Foods Hum Nutr 65:253-259. https://doi.org/10.1007/ s11130-010-0189-x

Flores-Valdez C (2001) Produção, industrialização e comercialização de verdura de palma forrageira. In: Barbera G, Inglese P (eds) Agroecologia, cultivos e usos da palma forrageira. Sebrae Paraiba, Brazil, pp 94-102

Forzza RC, Baumgratz JFA, Bicudo CEM et al (2012) New Brazilian floristic list highlights conservation challenges. Bioscience 62:39-45. https://doi.org/10.1525/bio.2012.62.1.8

Galati E, Pergolizzi S, Miceli N et al (2002a) Study on the increment of the production of gastric mucus in rats treated with Opuntia ficus indica (L.) Mill. cladodes. J Ethnopharmacol 83:229-233. https://doi.org/10.1016/S0378-8741(02)00243-X 
Galati E, Tripodo M, Trovato A et al (2002b) Biological effect of Opuntia ficus indica (L.) Mill. (Cactaceae) waste matter. J Ethnopharmacol 79:17-21. https://doi.org/10.1016/ S0378-8741(01)00337-3

Galati EM, Monforte MT, Miceli N et al (2007) Opuntia ficus indica (L.) Mill. mucilages show cytoprotective effect on gastric mucosa in rat. Phyther Res 21:344-346. https://doi.org/10.1002/ ptr.2075

Gomez-Flor R, Tamez-Guer P, Tamez-Guer R et al (2006) In vitro antibacterial and antifungal activities of nopalea cochenillifera pad extracts. Am J Infect Dis 2:1-8. https://doi.org/10.3844/ ajidsp.2006.1.8

Guevara-Figueroa T, Jiménez-Islas H, Reyes-Escogido ML et al (2010) Proximate composition, phenolic acids, and flavonoids characterization of commercial and wild nopal (Opuntia spp.). J Food Compos Anal 23:525-532. https://doi.org/10.1016/j.jfca.2009.12.003

Hoffmann W (2001) Etnobotânica. In: Barbera G, Inglese P (eds) Agroecologia, cultivos e usos da palma forrageira. Sebrae Paraiba, Brazil, pp 12-19

Hwang SH, Kang I-J, Lim SS (2017) Antidiabetic effect of fresh nopal (Opuntia ficus-indica) in low-dose streptozotocin-induced diabetic rats fed a high-fat diet. Evid Based Complement Altern Med 2017:1-8. https://doi.org/10.1155/2017/4380721

Karababa E, Coşkuner Y, Aksay S (2014) Some physical fruit properties of cactus pear (Opuntia spp.) that grow wild in the Eastern Mediterranean region of Turkey. J Prof Assoc Cactus Dev 2014:1-8

Kinupp V (2004) Barros I, Levantamento de dados e divulgação do potencial das plantas alimentícias alternativas no Brasil. 22:1-4

Kinupp V, Lorenzi H (2014) Plantas alimentícias não convencionais (PANC) no Brasil. Instituto Plantarum de Estudos da Flora, São Paulo

Lans CA (2006) Ethnomedicines used in Trinidad and Tobago for urinary problems and diabetes mellitus. J Ethnobiol Ethnomed 2:45. https://doi.org/10.1186/1746-4269-2-45

Leal ML, Alves RP, Hanazaki N (2018) Knowledge, use, and disuse of unconventional food plants. J Ethnobiol Ethnomed 14:1-9. https://doi.org/10.1186/s13002-018-0209-8

Leem K-H, Kim M-G, Hahm Y-T, Kim H (2016) Hypoglycemic effect of Opuntia ficus-indica var. saboten is due to enhanced peripheral glucose uptake through activation of AMPK/p38 MAPK pathway. Nutrients 8:1-15. https://doi.org/10.3390/nu8120800

Lima R (2016) Caracterização e potencial antioxidante do fruto da palma (Tacinga inamoena) e do mandacaru (Cereus jamacaru). Dissertation, Federal Rural University of the Semi-arid Region

Liu M, Li XQ, Weber C et al (2002) Antioxidant and antiproliferative activities of raspberries. J Agric Food Chem 50:2926-2930. https://doi.org/10.1021/jf0111209

Lucena CM, da Costa GM, de Sousa RF et al (2012) Conhecimento local sobre cactáceas em comunidades rurais na mesorregião do sertão da Paraíba (Nordeste, Brasil). Biotemas 25:281-291. https://doi.org/10.5007/2175-7925.2012v25n3p281

Lucena CM, Lucena RF, Costa GM et al (2013) Use and knowledge of Cactaceae in Northeastern Brazil. J Ethnobiol Ethnomed 9:1-11. https://doi.org/10.1186/1746-4269-9-62

Lucena C, Carvalho T, Ribeiro JES et al (2015) Conhecimento botânico tradicional sobre cactáceas no semiárido do Brasil. Gaia Sci 9:77-90

Lyra M, Silva M, Mergulhão A et al (2015) Molecular studies of forage prickly-pear cactus from the semiarid of Pernambuco State-Brazil. J Appl Biol Biotechnol 3:1-5. https://doi.org/10.7324/ jabb.2015.3201

Machado T (2019) Desenvolvimento de farinha de xiquexique (Pilosocereus gounellei): caracterização nutricional, propriedades funcionais e sua utilização na elaboração de cookies. Thesis, Federal University of the Paraíba

Machado J, Lucena C, Santos S et al (2018) Conhecimento botânico local sobre cactáceas: um estudo de caso no município de Boqueirão, Paraíba, Nordeste, Brasil. Flovet 1:1-21

Maciel J, Chaves O, Brito Filho S et al (2015) New alcamide and anti-oxidant activity of Pilosocereus gounellei A. Weber ex K. Schum. Bly. ex Rowl. (Cactaceae). Molecules 21:1-13. https://doi.org/10.3390/molecules21010011 
Mancuso S (2019) Revolução das plantas: um novo modelo para o future. Ebu, São Paulo

Martins A (2018) Elaboração de iogurte caprino com potencial funcional adicionado de geleia de frutos de mandacaru (Cereus jamacaru) e de maracujazeiro amarelo (Passiflora edulis Sims): Caracterização e avaliação do efeito protetor da matriz alimentar. Dissertation, Federal University of Campina Grande

Matias A, Nunes SL, Poejo J et al (2014) Antioxidant and anti-inflammatory activity of a flavonoidrich concentrate recovered from Opuntia ficus-indica juice. Food Funct 5:3269-3280. https:// doi.org/10.1039/C4FO00071D

Mayworm M, Salatino A (1996) Teores de óleo e composição de ácidos graxos de sementes de Cereus jamacaru DC. (Cactaceae), Zizyphus joazeiro Mart. (Rhamnaceae) e Anadenanthera colubrina 90 (Benth) Brenan var cebil (Griseb.) Von Altschul. (Mimosaceae). Sitientibus 15:201-209

Medeiros IU, Medeiros RA, Bortolin RH et al (2019) Genotoxicity and pharmacokinetic characterization of Cereus jamacaru ethanolic extract in rats. Biosci Rep 39:1-11. https://doi. org/10.1042/BSR20180672

Melo RDS, Silva SDM, De Sousa ASB et al (2017) Maturação e qualidade de frutos de mandacaru (Cereus jamacaru P.DC.) de diferentes bioclimas do estado da Paraíba. Agropecuária Técnica 38:160-168. https://doi.org/10.25066/agrotec.v38i3.33818

Menezes R, Simões D, Sampaio E (2005) A palma no Nordeste do Brasil - Conhecimento atual e novas perspectivas de uso. Rural Federal University of Pernambuco, Recife

Monteiro ER, Strioto DK, Meirelles ACS et al (2015) Genetic structure of Pilosocereus gounellei (Cactaceae) as revealed by AFLP marker to guide proposals for improvement and restoration of degraded areas in Caatinga biome. Genet Mol Res 14:16966-16974. https://doi. org/10.4238/2015.December. 15.2

Moreira IS, Silva LM, Castro DS et al (2018) Fruit of mandacaru: kinetics of drying and physicalchemical characterization. J Agric Sci 10:461-470. https://doi.org/10.5539/jas.v10n11p461

Mota TR, Linhares HVS, Araújo-Filho JH et al (2019) Protein extract from Cereus jamacaru (DC.) inhibits Colletotrichum gloeosporioides growth by stimulating ROS generation and promoting severe cell membrane damage. Microb Pathog 130:71-80. https://doi.org/10.1016/j. micpath.2019.02.033

Mouhaddach A, El-hadi A, Taghzouti K et al (2017) Assessment of Opuntia ficus-indica in vivo following ethnobotanical survey: confirmation of its analgesic activity. Phytothérapie. https:// doi.org/10.1007/s10298-017-1109-4

Moussa-Ayoub TE, El-Samahy SK, Kroh LW, Rohn S (2011) Identification and quantification of flavonol aglycons in cactus pear (Opuntia ficus indica) fruit using a commercial pectinase and cellulase preparation. Food Chem 124:1177-1184. https://doi.org/10.1016/j. foodchem.2010.07.032

Nascimento VT, de Moura NP, da Silva Vasconcelos MA et al (2011) Chemical characterization of native wild plants of dry seasonal forests of the semi-arid region of northeastern Brazil. Food Res Int 44:2112-2119. https://doi.org/10.1016/j.foodres.2010.12.024

Nascimento VT, Vasconcelos MA, Maciel MIS, Albuquerque UP (2012) Famine foods of Brazil's seasonal dry forests: ethnobotanical and nutritional aspects. Econ Bot 66:22-34. https://doi. org/10.1007/s12231-012-9187-2

Necchi RMM, Maki TDT, do Canto GS et al (2011) Antiinflammatory activity and biochemical parameters of the ethanol extract of Nopalea cochenillifera (L.) Salm-Dyck (Cactaceae). Lat Am J Pharm 30:786-789

Neves E (2006) Arqueologia da Amazônia. Rio de Janeiro

Nobel P (2001) Biologia ambiental. In: Agroecologia, cultivo e usos da palma forrageira. Sebrae Paraiba, João Pessoa, pp 36-48

Nobréga A (2019) Tratamento superficial para Blocos de Terra Comprimida (BTC): avaliação do potencial da mucilagem de xique-xique (Pilosocereus gounellei). Dissertation, Federal University of Paraíba 
Nunes CS (2011) Usos e aplicações da palma forrageira como uma grande uses and applications palm forage as a major source of economy for the semiarid. Rev verde Agroecol e Desenvolv sustentável 6:58-66

Oliveira F, Alexandre H, Figueirêdo R (2004) Características físico-químicas da polpa e casca do fruto do mandacaru. In: Congresso Brasileiro de Ciência e Tecnologia de Alimentos. Recife, Brazil

Oliveira ASC, Cavalcante Filho FN, Rangel AHDN, Lopes KBDP (2011) A palma forrageira: alternativa para $\mathrm{O}$ semi-árido the cactus pear: alternative to the semi-arid. Rev Verde Agroecol e Desenvolv Sustentável 6:49-58

Oliveira AS, Figueirêdo RM, Queiroz AJ, Brito JG (2015) Estabilidade da polpa do Cereus jamacaru em pó durante o armazenamento. Rev Bras Eng Agrícola e Ambient 19:147-153. https:// doi.org/10.1590/1807-1929/agriambi.v19n2p147-153

Oliveira AM, Luna Freire MO, Silva WAV et al (2018) Saline extract of Pilosocereus gounellei stem has antinociceptive effect in mice without showing acute toxicity and altering motor coordination. Regul Toxicol Pharmacol 95:289-297. https://doi.org/10.1016/j.yrtph.2018.04.004

Oliveira AM, Silva WAV, Ferreira MRA et al (2019) Assessment of 28-day oral toxicity and antipyretic activity of the saline extract from Pilosocereus gounellei (Cactaceae) stem in mice. J Ethnopharmacol 234:96-105. https://doi.org/10.1016/j.jep.2019.01.036

Oliveira AM, Freitas AFS, Paiva PMG, Napoleão TH (2020) Genotoxicity assessment of saline extract from Pilosocereus gounellei (Cactaceae) and its chemopreventive effect against cyclophosphamide-induced DNA damage. Heliyon 6:e03811. https://doi.org/10.1016/j.heliyon.2020.e03811

Park E-H, Kahng J-H, Lee SH, Shin K-H (2001) An anti-inflammatory principle from cactus. Fitoterapia 72:288-290. https://doi.org/10.1016/S0367-326X(00)00287-2

Paulino R, Henriques G, Coelho M, Araújo V (2011) Riqueza e importância das plantas medicinais do Rio Grande do Norte. Rev Biol e Ciências da Terra 11:157-168

Peron A (2011) Esterases para a análise de variabilidade genética em mandacaru (Cactaceae). State University of Maringá

Pessoa A (1967) Cultura da palma-forrageira. Sudene, Recife

Ribeiro TS, Sampaio KB, Menezes FNDD et al (2020) In vitro evaluation of potential prebiotic effects of a freeze-dried juice from Pilosocereus gounellei (A. Weber ex K. Schum. Bly. Ex Rowl) cladodes, an unconventional edible plant from Caatinga biome. 3 Biotech 10:1-9. https://doi.org/10.1007/s13205-020-02442-8

Rocha EA, Agra MF (2002) Flora do Pico do Jabre, Paraíba, Brasil: Cactaceae juss. Acta Bot Brasilica 16:15-21. https://doi.org/10.1590/S0102-33062002000100004

Rocha Filho CAA, Karla Amorim P, de Albuquerque Lima T et al (2019) PgTI, the first bioactive protein isolated from the Cactus Pilosocereus gounellei, is a trypsin inhibitor with antimicrobial activity. Adv Res:1-11. https://doi.org/10.9734/air/2019/v20i330160

Rockenbach II, Rodrigues E, Gonzaga LV et al (2011) Phenolic compounds content and antioxidant activity in pomace from selected red grapes (Vitis vinifera L. and Vitis labrusca L.) widely produced in Brazil. Food Chem 127:174-179. https://doi.org/10.1016/j.foodchem.2010.12.137

Rodrigues L, Elesb R (2009) Avaliação da composição físico-química de frutos de mandacaru (Cereus jamacaru P.). Acta Agronómica 58:245-250

Roque A, Rocha R, Loiola MI (2010) Uso e diversidade de plantas medicinais da Caatinga na comunidade rural de Laginhas, município de Caicó, Rio Grande do Norte (Nordeste do Brasil). Rev Bras Plantas Med 12:31-42. https://doi.org/10.1590/S1516-05722010000100006

Rosado V, Rosado A (1960) Plantas do Nordeste especialmente do Ceará, 2nd edn. Imprensa Oficial, Fortaleza

Saenz C (2000) Processing technologies: an alternative for cactus pear (Opuntia spp.) fruits and cladodes. J Arid Environ 46:209-225. https://doi.org/10.1006/jare.2000.0676

Sáenz-Hernández D (2001) Fabricação de alimentos e obtenção de subprodutos. In: Barbera G, Inglese P (eds) Agroecologia, cultivos e usos da palma forrageira. Sebrae Paraiba, Brazil, pp 140-146 
Sales M, Martins L, Souza I et al (2014) Cereus jamacarude Candolle (Cactaceae), o mandacaru do nordeste brasileiro. Publ UEPG Ciencias Biol e da Saude 20:135-142. https://doi.org/10.5212/ Publ.Biologicas.v.20i2.0006

Santos I (2018) Compostos fenólicos totais e atividade antioxidante da casca do fruto do mandacaru (Cereus jamacaru) em pó obtido em secador de leito fixo. Dissertation, Federal University of Campina Grande

Santos Neto JP, Silva VDN, Silva PA et al (2019) Características Físico-Químicas de Frutos de Mandacaru (Cereus Jamacaru P. Dc.) Cultivados no Sertão Alagoano. Rev Craibeiras Agroecol 4:e7741

Santos LA, Lima AMP, Passos IV et al (2001) Uso e percepções da alimentação alternativa no estado da Bahia: um estudo preliminar. Rev Nutr 14:35-40. https://doi.org/10.1590/ S1415-52732001000400006

Santos D, Farias I, Lira M et al (2006) Manejo e utilização da palma forrageira (Opuntia e Nopalea) em Pernambuco. IPA, Recife

Santos CAG, Dantas MK, Medeiros MFT (2017) Reports of knowledge and the uses of cactaceae species in the historia naturalis brasiliae (1648): comparative past-present analyses. Ethnos 2:1-19. https://doi.org/10.22276/ethnoscientia.v2i1.43

Santos NC, Almeida RLJ, da Silva LRI et al (2020) Pasteurização da polpa e da casca do fruto do mandacaru (Cereus jamacaru). Res Soc Dev 9:e403974027. https://doi.org/10.33448/ rsd-v9i7.4027

Saraiva ME, Ulisses AVR, Ribeiro DA, et al (2015) Plant species as a therapeutic resource in areas of the savanna in the state of Pernambuco, Northeast Brazil. J Ethnopharmacol 171:141-153. https://doi.org/10.1016/j.jep.2015.05.034

Sariburun E, Şahin S, Demir C et al (2010) Phenolic content and antioxidant activity of raspberry and blackberry cultivars. J Food Sci 75:328-335. https://doi.org/10.1111/j.1750-3841.2010.01571.x

Scheinvar L (1985) Cactáceas. Flora Ilustrada Catarinense, Itajaí

Shetty AA, Rana MK, Preetham SP (2012) Cactus: a medicinal food. J Food Sci Technol 49:530-536. https://doi.org/10.1007/s13197-011-0462-5

Silva V (2015) Diversidade de uso das cactáceas no Nordeste do Brasil: uma revisão. Gaia Sci 9:175-182. https://doi.org/10.21707/gs.v9i2.26476

Silva G (2017) Cereus jamacaru DC.: Perfil fitoquímico e avaliação citotóxica. Dissertation, Federal University of Pernambuco

Silva F, Albuquerque UP, Costa Júnior LM et al (2014) An ethnopharmacological assessment of the use of plants against parasitic diseases in humans and animals. J Ethnopharmacol 155:1332-1341. https://doi.org/10.1016/j.jep.2014.07.036

Silva APG, Souza CCE, Ribeiro JES et al (2015a) Características físicas, químicas e bromatológicas de palma gigante (Opuntia ficus-indica)e miúda (Nopalea cochenillifera) oriundas do estado da Paraíba. Rev Bras Tecnol Agroindustrial 9:1810-1820. https://doi.org/10.3895/ rbta.v9n2.1616

Silva DM, Carvalho FR, Moura AG et al (2015b) Cytotoxic action of the stem aqueous extract of the stem of Cereus jamacaru DC. (mandacaru) Acción citotóxica del extracto acuoso del tallo de Cereus jamacaru DC. (mandacaru). Rev Cuba Plantas Med 19:226-234

Silva LFCR, Valle L, Nascimento ARC, Medeiros MFT (2019) Cereus jamacaru DC. (Cactaceae): from 17th century naturalists to modern day scientific and technological prospecting. Acta Bot Brasilica 33:191-197. https://doi.org/10.1590/0102-33062018abb0352

Sousa MSB, Vieira LM, de Lima A (2011) Fenólicos totais e capacidade antioxidante in vitro de resíduos de polpas de frutas tropicais. Braz J Food Technol 14:202-210. https://doi. org/10.4260/BJFT2011140300024

Sousa A, Lima L, Calou I (2014) Teor de antocianinas e flavonoides amarelos presentes na casca e polpa do fruto do mandacaru (Cereus jamacaru). In: VII Simpósio Iberoamericano de Plantas Medicinais and II Simpósio Iberoamericano de Investigação em Câncer

Sousa GA, Oliveira IS, Silva-Freitas FV et al (2018) Gastroprotective effect of ethanol extracts of cladodes and roots of Pilosocereus gounellei (A. Weber ex K. Schum.) Bly. Ex Rowl 
(Cactaceae) on experimental ulcer models. J Ethnopharmacol 218:100-108. https://doi. org/10.1016/j.jep.2018.02.009

Stintzing FC, Carle R (2005) Cactus stems (Opuntia spp.): a review on their chemistry, technology, and uses. Mol Nutr Food Res 49:175-194. https://doi.org/10.1002/mnfr.200400071

Stintzing FC, Schieber A, Carle R (2001) Phytochemical and nutritional significance of cactus pear. Eur Food Res Technol 212:396-407. https://doi.org/10.1007/s002170000219

Tahir A, Elkheir M, Yagoub A (2007) Effect of tree and nodule age on some physicochemical properties of gum from Acacia senegal (L.) Wild., sudan. Res J Agric Biol Sci 3:866-870

Trombetta D, Puglia C, Perri D et al (2006) Effect of polysaccharides from Opuntia ficus-indica (L.) cladodes on the healing of dermal wounds in the rat. Phytomedicine 13:352-358. https:// doi.org/10.1016/j.phymed.2005.06.006

Uprety Y, Poudel RC, Shrestha KK et al (2012) Diversity of use and local knowledge of wild edible plant resources in Nepal. J Ethnobiol Ethnomed 8:16. https://doi.org/10.1186/1746-4269-8-16

Vázquez-Ramírez R, Olguín-Martínez M, Kubli-Garfias C, Hernández-Muñoz R (2006) Reversing gastric mucosal alterations during ethanol-induced chronic gastritis in rats by oral administration of Opuntia ficus-indica mucilage. World J Gastroenterol 12:4318. https://doi.org/10.3748/ wjg.v12.i27.4318

Viana AD, Corrêa JLG, Justus A (2014) Optimisation of the pulsed vacuum osmotic dehydration of cladodes of fodder palm. Int J Food Sci Technol 49:726-732. https://doi.org/10.1111/ ijfs. 12357

World Health Organization WHO (2002) Traditional Medicine Strategy 2002-2005

Zappi D, Taylor N (2020) Cactaceae. In: Flora do Brasil 2020 em construção. Botanical Gardel of Rio de Janeiro

Zappi D, Taylor N, Santos M, Larocca J (2015) Cactaceae. In: Lista de Espécies da Flora do Brasil. Botanical Gardel of Rio de Janeiro

Zhishen J, Mengcheng T, Jianming W (1999) The determination of flavonoid contents in mulberry and their scavenging effects on superoxide radicals. Food Chem 64:555-559. https://doi. org/10.1016/S0308-8146(98)00102-2 